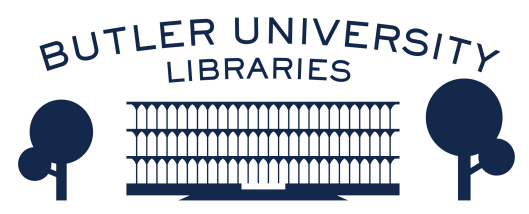

Journal of Hindu-Christian Studies

Volume 27

Article 5

November 2014

\title{
Between and Beyond Canons: Mirabai and Hadewijch in Relation to Scripture and the Self
}

Holly Hillgardner

Bethany College

Follow this and additional works at: https://digitalcommons.butler.edu/jhcs

Part of the History of Religions of Eastern Origins Commons

\section{Recommended Citation}

Hillgardner, Holly (2014) "Between and Beyond Canons: Mirabai and Hadewijch in Relation to Scripture and the Self," Journal of Hindu-Christian Studies: Vol. 27, Article 5.

Available at: https://doi.org/10.7825/2164-6279.1577

The Journal of Hindu-Christian Studies is a publication of the Society for Hindu-Christian Studies. The digital version is made available by Digital Commons @ Butler University. For questions about the Journal or the Society, please contact cbauman@butler.edu. For more information about Digital Commons @ Butler University, please contact digitalscholarship@butler.edu. 


\section{Between and Beyond Canons: Mirabai and Hadewijch in Relation to Scripture and the Self Holly Hillgardner Bethany College}

THIS was a woman who loved the taste of love, and Ram knows no high, no low.

\section{-Mirabai}

He who wishes to taste veritable Love, Whether by random quest or sure attainment, Must keep to neither path nor way.

-Hadewijch

Mirabai, a sixteenth century bhakta, wrote passionate songs of her desire for God. Burning for him, she employed the genre of virahabhakti, a mystical eroticism of longing from the Vaișnava tradition, as she begged for him to "[c]ome and extinguish the fire of separation." Hadewijch, a thirteenth-century Beguine from low-country Europe, wrote poems, letters, and prose that tell of her longing to become Love itself-to be "God with God." 2 Despite their myriad differences across traditions, miles, and years, Hadewijch and Mirabai can each be said to practice love-longing as her primary contemplative mode. The word "contemplation," from the Latin, refers to an attentive gazing; yet, longing, with its connotations of bodily eros, hints at a multisensory observational mode that goes beyond the single sense of sight. The epigraphs above, for example, display each woman longing to taste the divine. Both excerpts are part of longer pieces, explored later in this essay, which offer guidance for those cultivating contemplative paths of longing, which, for each of these authors, are communal practices to be shared with others. Enlisting these two medieval women as guides for my comparative investigation into yearning's transformative, broadening powers, I invite a contemplation of their juxtaposed practices of longing.

For this comparative theological experiment, I offer "focus texts" of Hadewijch's and Mirabai's writing that speak to the poignant love-longing that saturates their words and worlds. These texts cannot, of course, be read as the ultimate representations of the work of these women; it is important to acknowledge their layered, polyvalent texts; their diverse, concomitant traditions; and the full array of riches that emerge in a careful, comparative reading of them. For this essay,

Holly Hillgardner is Assistant Professor of religious studies and philosophy at Bethany College in Bethany, WV. A comparative theologian, her other academic interests include eco-feminist theologies, mysticism across traditions, yoga studies, and transformative pedagogies. To date, she has contributed an essay to Divine Multiplicity: Trinities, Diversities, and the Nature of Religion, ed. Chris Boesel and S. Wesley Ariarajah (New York: Fordham Press, 2013). She is at work on a book, tentatively entitled Longing and Letting Go: Christian and Hindu Practices of Passionate Non-attachment. 
however, I choose focus texts that help me concentrate on three points regarding the topic of "canons and contemplation." Contemplation, of course, covers a wide range of devotional activities, but I narrow the focus to practices of longing for love. As I narrow the term "contemplation" to practices of love-longing, I also broaden the term "canon" to mean not just ecclesial boundaries that mark off dogma, but also a more general sense of "model," from the Greek etymology. Accordingly, I suggest that Mirabai's and Hadewijch's practices of lovelonging 1) stretch the boundaries that operate around their traditions' canons of scripture and 2) make porous the borders that separate the self from others. As a third point, I submit that the relationship between contemplative practices of longing and comparative theological study might reveal similar forces of expansion and connection. In other words, through the multiplication of longing that comparison may entail-in this case, a compounding of Mirabai's, Hadewijch's, this author's, and readers' longings-something may be learned about the workings of interreligious comparison.

As I bring Mirabai's and Hadewich's texts of longing together, as one point of focus, I invite a noticing of each woman's longing to taste love. In the following lines from one of her letters, Hadewijch encourages her fellow Beguines in their questing after Love (Minne), which is a female-gendered word of fantastically flexible valence in Middle Dutch. ${ }^{3}$ First, she combines the genre of secular courtly love, which employed imagery of bravery and battle, along with the genre of bridal mysticism, known for its use of Song of Songs, to detail how one might dare to "conquer" the "Beloved":
God be with you and give you

True knowledge of the methods of Love;

May he enable you to understand

What the Bride says in the Song of Songs:

I to my Beloved, and my Beloved to me!

If anyone allowed Love to conquer him,

He would then conquer Love completely.

Next, she offers her advice to all who wish "to taste veritable Love":

I hope this will be your experience;

And although we are waiting long for the event,

Let us thank Love for everything.

He who wishes to taste veritable Love,

Whether by random quest or sure attainment,

Must keep to neither path nor way.

He must wander in search of victory over Love,

Both on the mountains and in the valleys, Devoid of consolation, in pain, in trouble; Beyond all the ways men can think of, That strong steed of Love bears him.

Finally, she discusses the indispensability of Love for contemplation-for seeing "to the depths of the Beloved." she ends this part of the letter abruptly, as she acknowledges the divine excess that cannot be fully possessed.

For reason cannot understand

How love, By Love, sees to the depths of the Beloved,

Perceiving how Love lives freely in all things.

Yes, when the soul has come to this liberty, The liberty that Love can give, It fears neither death nor life. 
however, I choose focus texts that help me concentrate on three points regarding the topic of "canons and contemplation." Contemplation, of course, covers a wide range of devotional activities, but I narrow the focus to practices of longing for love. As I narrow the term "contemplation" to practices of love-longing, I also broaden the term "canon" to mean not just ecclesial boundaries that mark off dogma, but also a more general sense of "model," from the Greek etymology. Accordingly, I suggest that Mirabai's and Hadewijch's practices of lovelonging 1) stretch the boundaries that operate around their traditions' canons of scripture and 2) make porous the borders that separate the self from others. As a third point, I submit that the relationship between contemplative practices of longing and comparative theological study might reveal similar forces of expansion and connection. In other words, through the multiplication of longing that comparison may entail-in this case, a compounding of Mirabai's, Hadewijch's, this author's, and readers' longings-something may be learned about the workings of interreligious comparison.

As I bring Mirabai's and Hadewich's texts of longing together, as one point of focus, I invite a noticing of each woman's longing to taste love. In the following lines from one of her letters, Hadewijch encourages her fellow Beguines in their questing after Love (Minne), which is a female-gendered word of fantastically flexible valence in Middle Dutch. ${ }^{3}$ First, she combines the genre of secular courtly love, which employed imagery of bravery and battle, along with the genre of bridal mysticism, known for its use of Song of Songs, to detail how one might dare to "conquer" the "Beloved":
God be with you and give you

True knowledge of the methods of Love;

May he enable you to understand

What the Bride says in the Song of Songs:

I to my Beloved, and my Beloved to me!

If anyone allowed Love to conquer him,

He would then conquer Love completely.

Next, she offers her advice to all who wish "to taste veritable Love":

I hope this will be your experience;

And although we are waiting long for the event,

Let us thank Love for everything.

He who wishes to taste veritable Love,

Whether by random quest or sure attainment,

Must keep to neither path nor way.

He must wander in search of victory over Love,

Both on the mountains and in the valleys, Devoid of consolation, in pain, in trouble; Beyond all the ways men can think of, That strong steed of Love bears him.

Finally, she discusses the indispensability of Love for contemplation-for seeing "to the depths of the Beloved." she ends this part of the letter abruptly, as she acknowledges the divine excess that cannot be fully possessed.

For reason cannot understand

How love, By Love, sees to the depths of the Beloved,

Perceiving how Love lives freely in all things.

Yes, when the soul has come to this liberty, The liberty that Love can give, It fears neither death nor life. 
42 Holly Hillgardner

The soul wants the whole of Love and wants nothing else.

-I leave rhyme: What mind can say eludes me. $^{4}$

As exemplified above, Hadewijch often employs scriptural images. As she engages with scripture, she finds it a platform for imaginative flights of wordplay and hybridized metaphorical schema. For example, she creates a genre that combines the traditional Christian bridal mysticism inherited from her religious tradition with the courtly love poetry prominent in her era. This hybrid genre, called mystique courtoise by Barbara Newman, describes Hadewijch's mixing of bridal mysticism-heavily influenced by scripturewith powerful, secular images of courtly love. ${ }^{5}$ For example, noticing her allusion to Song of Songs early in the above letter-in-verse, we also notice that further imagery carries connotations of a conquering knight on a difficult journey. She writes that the knight/lover "must wander in search of victory over Love/ Both on the mountains and in the valleys." This example represents one way that scripture serves as a springboard for her creative images and layered metaphors, which complexify and deepen her theological resonances as she longs for the taste of the divine.

The letters and poems of Hadewijch are not only reflections of her own experiences; they are best understood in their context as communally contemplative texts, ones employed for the spiritual formation of her fellow beguines, women who lived lives of devotion and service without taking formal vows. Her letters, visions, and stanzaic poems were likely read aloud to her community in a ritual of hearing the texts and participating in responsive song. ${ }^{6}$ In this way, these recited and sung texts took on some of the traditional roles-teaching, revealing, correcting, inspiring-of Christian scripture used for contemplation in such liturgical situations; thus, they likely functioned similarly to scriptures heard together in community.

Mirabai's songs, too, have functioned as foci for other's practices of contemplation. Devotional singers in her day joined their voices together to sing her songs as they communally yearned for the love of God. Mirabai's songs of longing became extended by others, who sometimes responded by writing new texts in Mirabai's name in their own yearning voices. Keeping the canon of Mirabai songs open even today, bhaktas across India and beyond sing songs attributed to Mirabai. ${ }^{7}$ Thus, any kind of individualized reading of Mirabai decontextualizes the relational powers of Mirabai's bhakti and forecloses upon the performative genre of her songs and their power in the lives of women. Mirabai's songs are "a collective oeuvre," Kumkum Sangari explains, one in which "songs are inscribed in an extended rather than discrete moment of production. They represent intentionalities, beliefs, and desires, which stretch beyond the individual and may be designated as a definable mode of social perception inhabited by Mirabai and nameless others." ${ }^{8}$ This mode of social perception lures Mirabai's desire for God into the present and future-beyond this one historical contemplative of the sixteenth century.

It is important to note here that both Mirabai's and Hadewijch's writings were composed in vernacular languages, instead of in the traditional languages used by the 
religious orthodoxies of their times. Writing in Middle Dutch rather than Latin, Hadewijch chose the language of many of her less educated Beguine sisters and other Christians living in the surrounding communities. In a similar manner, the bhakti movement is known for its embrace of the vernacular languages of local poets and singers, rather than the Sanskrit language of traditional Hindu scripture; indeed, Mirabai wrote in a local language that allowed bhakti devotional life to flourish widely. Thus, bhakti can represent a protest against both the class system, which limited access to Sanskrit, as well as against the elevation of Sanskrit as the primary mode for revelation. In these ways, Mirabai and Hadewijch participated in different countercultural religious movements that valued ordinary, outsider voices, including the voices of women.

Unlike Hadewijch, who drew from canonized scripture frequently, Mirabai, due to barred access, did not draw explicitly from the Vedas; however, some of her recurring images, such as those of Krishna and the gopis, are often congruent with descriptions in smrti scripture. She does, significantly, mention the Vedas in her famous song of the Bhil woman. While poor and low-caste, the woman lauded in this poem pleases God by offering a plum that she had tasted to ensure its perfect sweetness. The groups situated lowest in Mirabai's society, such as the Bhils, were seen by others as too impure to handle most other groups' food. ${ }^{9}$ Here, again, I invite a listening for the imagery of taste as Mirabai writes of the Bhil woman and the gift she offers God.

The Bhil woman tasted then, plum after plum, and finally found one she could offer him. What kind of genteel breeding was this? And hers was no ravishing beauty. Her family was poor, her caste quite low, her clothes a matter of rags,

Next, she describes Ram's response to such a woman who "loved the taste of love":

Yet Ram took that fruit-that touched, spoiled fruit-

for he knew that it stood for her love.

This was a woman who loved the taste of love,

and Ram knows no high, no low.

Here, note the allusion to the scriptures, which the woman never had an opportunity to learn, yet love connects her to God, regardless:

What sort of Veda could she ever have learned?

But quick as a flash she mounted a chariot And sped to heaven to swing on a swing, tied by love to God.

Mirabai ends this song with a prayerful encomium to the Lord who "cares for the fallen" and a request that all who love "as [the Bhil woman] did" find communion with God.

You are the Lord who cares for the fallen; rescue whoever loves as she did:

Let Mira, your servant, safely cross over, a cowherding Gokul girl. ${ }^{10}$

In this case, the Bhil woman first tastes and then offers fruit to Ram, and "that touched, spoiled fruit" is nonetheless well received by him. As she loves the taste of love, he accepts 
44 Holly Hillgardner

the taste of love she offers him. Taste functions first in this song as a barrier erected against the Bhil woman's love-longing, but Mirabai transforms taste into an image of divine and human mutual reciprocity. At the end of the song, Mirabai identifies herself as a passionate gopi, a "cowherding Gokul girl," but the song is primarily given over to the story of one who differs from Mirabai's famed breeding and beauty. As the Bhil woman "loved the taste of love," Mirabai, too, yearns to love like this, to "safely cross over" to be with God.

This song thus offers a vision for the leveling of caste distinctions toward a world that "knows no high, no low." Bhakti has long been understood as a democratizing religious energy, and as Mirabai highlights and identifies with the longing of the Bhil woman, the rigid boundaries between the two women radically soften. In the world imaged here, the poor Bhil woman and the poet-princess Mirabai, both barred from the traditional study of the scriptures, may find themselves "sped to heaven to swing on a swing, tied by love to God," as well as tied to each other by their common love for God. As she finds herself bound up with God and others, Mirabai's practices of longing point to her profoundly relational identity. As such, Mirabai's longing for God takes her more intensely into relationships in the world. According to her hagiography, loving as the Bhil women did, Mirabai leaves her scripted, courtly life and connects to the wider, unknown world. "[I]t's time to take my songs into the street," she proclaims in one song. ${ }^{11}$

Reading Hadewich and Mirabai together, one may see more clearly that neither does Hadewijch's love-longing cause her to retreat into a private, spiritualized sphere. Longing, in fact, widens her world. Each woman's respective longing for the divine not only takes her on an inward journey but also opens her up into an entangling involvement in the beauty and sufferings of her community. For Hadewijch, Love (Minne) does not send her deeply into a separative interiority; rather, she affirms, "Love makes me wander outside myself." 12 In another letter, Hadewijch describes this expanding sense of self as a fluid community in which God and "his friends, in mutual interpenetration, enjoy such blissful fruition, and are flowing into his goodness and flowing out again in all good." ${ }^{13}$ A widened Hadewijch finds herself in communion both with the divine and other longing selves.

As Hadewijch and Mirabai engaged in their respective practices of longing, a broadening of conventional religious identities also occurs. As illustrated by Mirabai's living as an itinerant bhakta, which would involve her traveling alone, and Hadewijch's becoming a Beguine, which can be seen a third option between the nunnery and marriage, each woman constructed religious identities that were at odds with the dominant religious options available for women in their times. Many persons working in comparative theology and related fields have experienced the practices of their disciplines expanding their religious identities, a process that may result in hyphenated understandings of the self. Elaborating on the idea of the hyphen, Francis $\mathrm{X}$. Clooney envisions it helping to describe those for whom multiple religious pathways are deeply meaningful, without asking them to choose one path exclusively. ${ }^{14}$ For example, in a Hindu-Christian identity, the hyphen extends in both directions between "Hindu" and "Christian," which represents an exchange of 
bi-directional currents that do not collapse the traditions into each other. In the hyphen, the space of difference is sustained between traditions, even as they are brought together in relation. Practices of longing, I submit, can help create and sustain the middle space of the hyphen. In conclusion to this short, comparative contemplation of the power of love-longing for Hadewijch and Mirabai, I gesture to the potential for practices of longing to help comparative theologians, or those in related fields, practice our disciplines with a more commodious, hospitable sense of the religiously-plural self. I turn back to readings of Hadewijch and Mirabai to elucidate the middle spaces through a further contemplation of their different paths of longing. To those the path of love-longing, Hadewijch offers the following blessing:

May Love herself make you experience How with love one loves in Love,

May her nature make you understand in fiery longing

How one sees with longing in longing. ${ }^{15}$

Here, in the first two lines, she writes of Minne and densely describes what could be called a non-dualism-"how with love one loves in Love." Then, in the following two lines, echoing the syntax of the previous couplet, she refers to longing in parallel terms with Love, which lends an explicit cast of divinity to longing itself. Hadewijch's wordplay with "Love" and "longing" points to her whole world becoming love-longing. Furthermore, she refers to longing as the way one should see, observe, or contemplate the world; that is, she proposes a certain epistemology, a way of knowing through the practices of longing. In
Mirabai's bhakti, her cultivation of longing similarly involves embracing longing as a way of knowing; that is, sharing aspects of grief and pleasure, bhaktas relate to each other in and through these emotions. In communities born of and sustained by longing, bhaktas "produce" and "intensify" emotions together in dance, poetry, song, and music. ${ }^{16}$ These emotions may then inform the way they live together in the world.

"Epistemologies of longing" name how yearning informs both woman's every actionfrom Hadewijch's advising her fellow Beguines in the ways of Love to Mirabai's running off with the bhaktas. Longing is what each knows and how each knows. Longing, for Hadewich, thus names a certain kind of eros, one that embraces the fullness of life with its inevitable loves, griefs, and other mutual entanglements. As we have seen thus far, Hadewijch's longing includes not just blissful moments of mutual "interpenetration" among friends, a la Hadewijch's description above, but also the knight/lover who wanders, in the words of the Hadewijch focus text, "[b]oth on the mountains and in the valleys,/ Devoid of consolation, in pain, in trouble." ${ }^{17}$ For Mirabai, viraha-bhakti's primary dynamic involves movements between the poles of full divine presence and full divine absence; thus, her love-longing similarly involves not only goodness, mutuality, and beauty, but also brings intense grief, confusion, and separation into the mix. She acknowledges-sometimes with lamentation and sometimes with celebration-the "bittersweetness of love-in separation." ${ }^{18}$ Longing, as such, represents a deep hunger for wholeness and completion within frighteningly uncertain lives, but despite the fears it ignites, desire must pull back from its proclivity to try to 
46 Holly Hillgardner

possess that for which it longs. Both Mirabai and Hadewijch long to possess the divine before each realizes, not without some grief, both the futility and ultimately, undesirability of a grasping concupiscence. Each, in her own way, recognizes that some of longing's power may reside in its mode of incompletion-the middle spaces of longing between the poles of desire's absence and the extinguishing fulfillment of desire. It is in these middle spaces-where the erotic desire for union with God is mixed with the grief of the thwarting of that full union-where much of Mirabai's and Hadewijch's writing resides. Attaining any sort of final end to their longing is not the focus; instead, the middle spaces of longing are prized. On this account, longing is the sometimes painful, sometimes joyful presencein-absence that emerges when one discovers the object of desire cannot be possessed. Hadewijch's and Mirabai's brave dwelling in the middle spaces of longing, despite the difficulties of such paths, serve as resources for the possibilities of the hyphen between traditions-for the middle spaces of the "Hindu-Christian." Because the divine cannot be exclusively possessed by those from either tradition, we are reminded that a fuller understanding necessitates the insights of those who see differently. We are moved into the hyphen, where others' insights can change us.

In this comparative project, the practice of comparative theology led to a communal compounding of longing-Mirabai's, Hadewijch's, and mine. Those reading along with me also become co-contemplators of Hadewijch and Mirabai, with the opportunity to enter into collective longing. As we read Hadewijch and Mirabai together, these yearning women come into relationship with each other and us, and desire multiplies and deepens. Here, an epistemology of longing, one in which longing informs the work of comparative theology, begins to emerge. Desiring Mirabai and Hadewijch to speak their truths, but never being able to capture them fully, we, as comparativists, are moved into a middle space where we may be better capable of holding the texts and traditions lightly, without attempting to possess them for ourselves, an exclusive faith, or a certain scholarly tradition. Longing in this key provides resources for a whole-hearted engagement that does not colonize the other. By cultivating practices of longing, we may find ourselves to be less possessive, more generous partners in love and learning.

\section{Notes}

1 Mirabai, "Caturvedī's Pada 96," in The Devotional Poems of Mirābāī, ed. and trans. A.J. Alston (Delhi: Motilal Banarsidas, 1980), 74. http://dx.doi.org/2027/uc1.32106007118729.

${ }^{2}$ Hadewijch, "Letter 6: To Live Christ," in Hadewijch: The Complete Works, ed. and trans. Columba Hart, O. S. D. (New York: Paulist Press, 1980), line 229, 61. http://dx.doi.org/2027/mdp.39015029185595.

${ }^{3}$ One poem reads, "O love, were I love, and with love, love/you, love, O love, for love, give that love /which love may know wholly as love." Hadewijch, "Mengeldict 15," in The Measure of Mystic Thought, trans. Murk-Jansen, lines 49-52, 71. In Middle Dutch, the poem reads, "Ay minne ware ic minne/ Ende met minnen minne $v$ minne / Ay minne om minne gheuet dat minne / Die minne al minne volkinne." 
${ }^{4}$ Hadewijch, "Letter 19: To Have Nothing But God," in Hadewijch:The Complete Works, trans Hart, 88-9.

${ }^{5}$ See Barbara Newman, From Virile Woman to WomanChrist: Studies in Medieval Religion and Literature (Philadelphia: University of Pennsylvania Press, 1995), 164, http://dx.doi.org/2027/mdp.39015031709499, for a discussion of how fine amour and Brautmystik mutually shaped each other.

${ }^{6}$ Veerle Fraeters, forward to Hadewijch: WriterBeguine-Love Mystic, by Paul Mommaers with Elizabeth Dutton (Leuven, Belgium: Peeters, 2005), x. She points also to the work of Anikó Daróczi, Hadewijch. Ende hieromme swighic sachte (Amsterdam-Antwerp: Atlas, 2002).

${ }^{7}$ Hadewijch may also have served as the inspiration for pseudonymous authors-in her case, ones anchoring their writings in the Christian mystical Beguine tradition. Some scholars posit the existence of a Hadewijch II, and even a Hadewijch III, due to what they read as incongruous themes and literary conventions in the body of work traditionally attributed to her. See Saskia Murk-Jansen, The Measure of Mystic Thought: A Study of Hadewijch's Mengeldichten (Goppingen: Kummerle Verlag, 1991), 14-15, http://dx.doi.org/2027/ mdp.39015020653302, for a summary of these arguments.

${ }^{8}$ Kumkum Sangari, "Mirabai and the Spiritual Economy of Bhakti," Economic and Political Weekly (7-14 July 1990): 1466. http://www.jstor.org/stable/4396474.

${ }^{9}$ Bhils were often employed by the Rajputs, Mirabai's clan. The varna system can be seen in a classical formulation in the Rgveda's hymn to the "cosmic man."
${ }^{10}$ Mirabai, "Caturvedī's Pada 186," in Songs of the Saints of India, trans. John Stratton Hawley and Mark Juergensmeyer (New York: Oxford University Press, 2004), 137.

${ }^{11}$ Mirabai, "barasāṃ rī badariyā savān rī," in For Love of the Dark One, trans. Andrew Schelling (Prescott, AZ: Hohm Press, 1998), 26. http://dx.doi.org/2027/uc1.b4563602.

${ }^{12}$ Hadewijch, "Poems in Stanzas 6: Conquest of Love-At a Price," in Hadewijch, trans. Hart, line $49,143$.

${ }^{13}$ Hadewijch, "Letter 12: The Jacob Letter," in Hadewijch, trans. Hart, lines 57-9, 71.

${ }^{14}$ Francis X. Clooney, Comparative Theology: Deep Learning Across Religious Borders (Malden, MA; Wiley-Blackwell, 2010), 160-1. http://dx.doi.org/10.1002/9781444318951. Also, see Catherine Cornille, ed., Many Mansions? Multiple Religious Belonging and Christian Identity (Eugene, OR: Wipf \& Stock Publishers, 2010), in which Clooney also has an essay, for an introduction to the concept of multiple religious belonging.

${ }^{15}$ Hadewijch, "Couplet Poem 1: The Nature of Love," in Hadewijch, trans. Hart. lines 17-20, 311.

${ }^{16}$ Friedhelm Hardy, Viraha-Bhakti: The Early History of Krșna Devotion in South India (New Delhi: Oxford University Press, 1983), 575.

17 Hadewijch, "Letter 19" in Hadewijch:The Complete Works, trans. Hart, lines 14-5, 89.

${ }^{18}$ Diedre Green, "Living Between the World: Bhakti Poetry and the Carmelite Mystics," in The Yogi and the Mystic: Studies in Indian and Comparative Mysticism, ed. Karel Werner (Richmond, U. K.: Curzon Press, 1994), 134. 